\title{
A SPATIAL MODEL FOR PREDICTING THE OCCURENCES OF DEFORESTATION IN THE ISLAND OF SUMATRA, INDONESIA
}

\author{
MUHAMMAD NUR AIDI*1 AND SANDHI IMAM MAULANA ${ }^{2}$ \\ ${ }^{1}$ Department of Statistics, Faculty of Mathemathics and Natural Sciences, Bogor Agricultural University, Bogor 16680, \\ Indonesia. ${ }^{2}$ The Ministry of Environment and Forestry-Republic of Indonesia, Jakarta 12190, Indonesia.
}

*Corresponding author: nuraidi@yahoo.com

Submitted final draft: 15 March $2020 \quad$ Accepted: 27 April 2020

http://doi.org/10.46754/jssm.2020.08.007

\begin{abstract}
This study primarily aims to develop a spatial model for predicting the occurrences of deforestation in Sumatra Island, Indonesia. This study was conducted based on spatial logistic regression approach that has been widely acknowledged for its flexibility and ability to accept a mixture of both categorical and numerical variables. Result of this study shows that a combination between logistic regression-based modelling and Geographical Information System (GIS) is indeed suitable for determining the probability of deforestation occurrences in Sumatra Island. Analysis conducted in this study has also revealed that physiographic variables, soil type variables, as well as human activity variables have high significant correlation with deforestation. These findings are useful to assist policy makers in Indonesia to understand the process of deforestation and to take it into consideration while formulating land use-related decisions.
\end{abstract}

Keywords: Logistic regression, forest clearing, probability, land use, Sumatra.

\section{Introduction}

Sumatra is one of the largest and the most populated island in Indonesia, accommodating about $22 \%$ of the country's total population. In the next decade, it is projected that total population in Sumatra will likely to reach above 65 million people (BPS-Statistics Indonesia Indonesia, 2018). In regard to this high level of population number, there are many studies argued that population growth does have a significant influence on land use changes, involving forest clearing for agricultural purposes, wood extraction, as well as infrastructure and settlement expansions attributed to deforestation (DeFries et al., 2010; Sydenstricker-Neto, 2012).

Up to now, analyses on deforestation have often been grounded upon merely numericalstatistical data and have tended to pay less attention on its spatial context, whereas in fact, it is crucial to support policy makers in comprehending the whole process and take it into consideration when decision is made. Previously, (Prasetyo et al., 2009) had established a spatial model that can be used to predict future deforestation process in Java Island. In their study, deforestation is modeled following logistic regression approach, in which that the percentages of deforested area is defined as a response variable, while several factors, such as population density, elevation, slope and road density that explain spatial pattern of deforestation in Java were chosen as explanatory variables. Nevertheless, although this study has indicated current advances in the establishment of spatial modelling on deforestation, however, it should be kept in mind that the impact of population on deforestation in Indonesia is indeed site-specific.

Furthermore, it seems that studies in regard to spatial modelling for deforestations are very limited in Sumatra even though the island hold at least 21 million hectares of Indonesia's remaining forest area (BPS-Statistics Indonesia, 2018). Considering this issue, this study primarily aims to develop a spatial model for predicting the occurrences of deforestation in Sumatra Island, Indonesia. This study is conducted based on spatial logistic regression approach that has been widely acknowledged for its flexibility and ability to accept a mixture of both categorical and numerical variables. Deforestation is closely related to human activities, easy of access, and related to the 
presence of humic acrisol soil type at certain location. Those factors can be measured by the distance between residence to location, intensity of transportation around location, easy to reach location which can be realized by slope. Humic acrisol is a one of soil types. So, the independent variables were used in this model are distance to location from resident, road density, elevation, slope and soil type (Catry et al., 2009; Pan et al., 2016). The development of such spatial model is highly needed in order to assist policy makers in Indonesia to understand the process of deforestation and to take it into consideration while formulating land use-related decisions. Additionally, the result of this study can also be used as data input in solving environmental problems attributed to deforestation.

\section{Materials and Methods}

\section{Study Area}

This study was conducted in the island of Sumatra, Indonesia. Geographically, this island is located between $00^{\circ}$ North and $102^{\circ}$ East, while administratively, there are eight provinces in this island, namely Aceh, North Sumatra, Riau, West Sumatra, Jambi, Bengkulu, South Sumatra, and Lampung. According to (BPS-Statistics Indonesia, 2017), total land extent of this island is about $473.871 \mathrm{Km}^{2}$. As shown in Figure 1, Sumatra is an elongated landmass spanning a diagonal northwest-southeast axis. The Indian Ocean borders the west, northwest, and southwest coasts of Sumatra with the island chain of Simeulue, Nias and Mentawai off the western coast. In the northeast the narrow Strait of Malacca separates the island from the Malay Peninsula, which is an extension of the Eurasian continent. In the southeast the narrow Sunda Strait separates Sumatra from Java. The northern tip of Sumatra borders the Andaman Islands, while off the southeastern coast lie the islands of Bangka and Belitung, Karimata Strait and the Java Sea. The equator crosses the island at its center in West Sumatra and Riau provinces. The climate of the island is tropical, hot and humid. Lush tropical rain forest once dominated the landscape.

\section{Data Collection}

According to the projected coordinate system of Universal Transfer Mercator (UTM), the island of Sumatra is divided into five different zones, namely UTM 46-North, UTM 47-North, UTM 48-North, UTM 47-South and UTM 48-South. Hence, in order to unite this study area into a single coordinate zone, we used geographic coordinate system (GCS) based on World Geodetic Survey (WGS)-1984 datum. Consequently, measurement of distance related variable in this study was conducted using measurement unit of decimal degree, while measurement of density related variable was

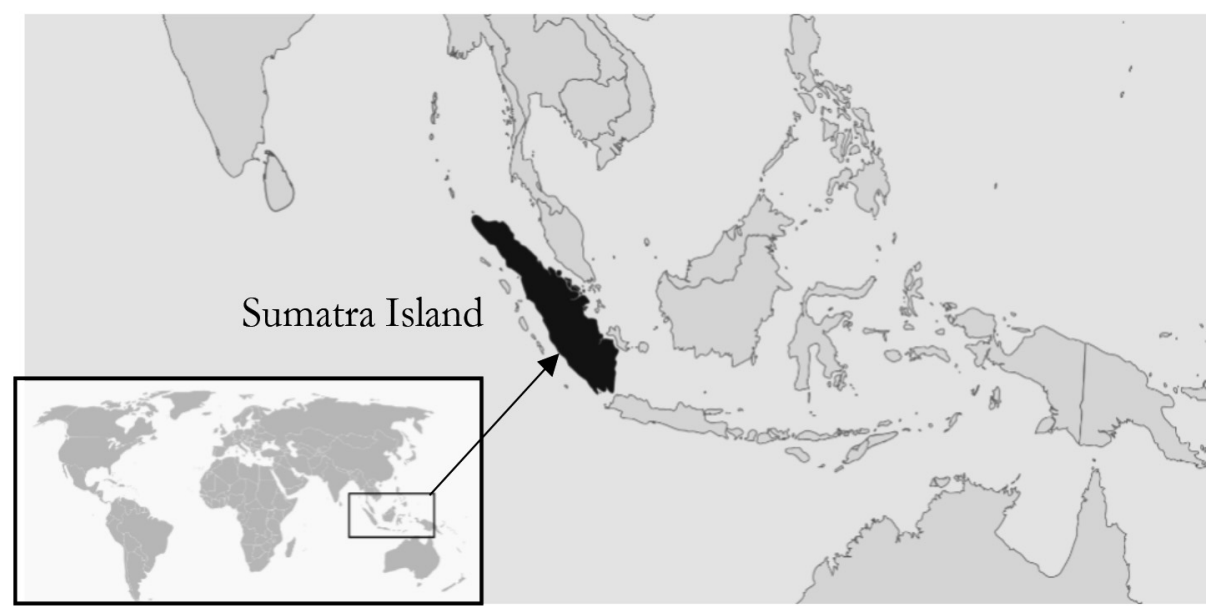

Figure 1: Study Area 
conducted using measurement unit of decimal degree/decimal degree ${ }^{2}$.

The dependent variable in this study is the deforested area in Sumatra Island, which is based on binary logistical approach for each cell sized $0.0045 \times 0.0045$ decimal degree or about $0.5 \times 0.5 \mathrm{~km}$, value of cell with detected deforestation will be defined as 1 , whilst cell with no deforested area will be defined as 0 . Meanwhile independent variables in this study are including physiographic variables (e.g. elevation and slope), soil type variables, as well as human activity variables (e.g. distance to residential area and road network density).

Data for dependent variable, which is the occurrence of deforestation, were calculated from the difference between Intact Forest Landscapes Map of 2000 and 2016 gathered from the World Resources Institute (WRI). Meanwhile, in regard to independent variables, data for elevation and slope were extracted from Shuttle Radar Topography Mission (SRTM)Digital Elevation Model (DEM) provided by the United States Geological Survey (USGS). In order to obtain soil type data of Sumatra, we use World Soil Map that were obtained from the Food and Agricultural Organization (FAO). In the meantime, data related to road density and distance to residential area were generated from Indonesian Topographic Map from the Agency for Geospatial Information-Republic of Indonesia. Detailed data types and sources used in this study are presented in Table 1.

Table 1: Details of data types and sources

\begin{tabular}{|c|c|c|c|}
\hline Category & Data & Type & Source \\
\hline $\begin{array}{l}\text { D e p e n d e } \mathrm{nt} \\
\text { Variable }\end{array}$ & $\begin{array}{l}\text { Deforestation } \\
\text { area }\end{array}$ & $\begin{array}{l}\text { Numerical-binary data }(1= \\
\text { deforestation occured; } 0= \\
\text { no deforestation })\end{array}$ & $\begin{array}{l}\text { Analyzed from the difference between } \\
\text { Intact Forest Landscapes Map of } 2000 \\
\text { and } 2016 \text { provided by World Resources } \\
\text { Institute (WRI) }\end{array}$ \\
\hline \multirow{5}{*}{$\begin{array}{l}\text { Independent } \\
\text { Variables }\end{array}$} & $\begin{array}{l}\text { Distance to } \\
\text { residential area }\end{array}$ & $\begin{array}{l}\text { Numerical data measured } \\
\text { in decimal degree }(\mathrm{dd})\end{array}$ & $\begin{array}{l}\text { Generated from Indonesian Topographic } \\
\text { Map of } 2016 \text { from the Agency for } \\
\text { Geospatial Information-Republic of } \\
\text { Indonesia }\end{array}$ \\
\hline & Road density & $\begin{array}{l}\text { Numerical data measured } \\
\text { in decimal degree/decimal } \\
\text { degree }^{2}\left(\mathrm{dd} / \mathrm{dd}^{2}\right)\end{array}$ & $\begin{array}{l}\text { Generated from Indonesian Topographic } \\
\text { Map of } 2016 \text { from the Agency for } \\
\text { Geospatial Information-Republic of } \\
\text { Indonesia }\end{array}$ \\
\hline & Elevation & $\begin{array}{l}\text { Numerical data measured } \\
\text { in meter above sea level } \\
\text { (m.asl) }\end{array}$ & $\begin{array}{l}\text { Generated from Shuttle Radar } \\
\text { Topography Mission (SRTM)-Digital } \\
\text { Elevation Model (DEM) of } 2008 \\
\text { provided by the United States Geological } \\
\text { Survey (USGS) }\end{array}$ \\
\hline & Slope & $\begin{array}{l}\text { Numerical data measured } \\
\text { in percent }(\%)\end{array}$ & $\begin{array}{l}\text { Generated from Shuttle Radar } \\
\text { Topography Mission (SRTM)- } \\
\text { Digital Elevation Model (DEM) of } \\
2008 \text { provided by the United States } \\
\text { Geological Survey (USGS) }\end{array}$ \\
\hline & Soil type & $\begin{array}{l}\text { Categorical data consisting } \\
\text { of eleven classes }\end{array}$ & $\begin{array}{l}\text { Extracted from World Soil Map of } 2007 \\
\text { that was obtained from the Food and } \\
\text { Agricultural Organization (FAO) }\end{array}$ \\
\hline
\end{tabular}




\section{Model Development}

Model development was initialized by partitioning the gathered data into two separate data sets, which are training data set and testing data set. For this purpose, the stratification random data partition approach is used (to partition the data that has been collected), in which that gathered data were firstly stratified into eleven strata based on soil type. Afterwards, for each stratum, the data were proportionally and randomly divided with proportion of $80 \%$ for training data that be used for model development, and the rest of $20 \%$ were kept as testing data set that be used for model validation. Details of data partitioned per stratum in this study is shown in Table 2, where it can be seen that total cell population $(\mathrm{N})$ in this study was 162165 cells. All in all, $80 \%$ of that cell population, or about 129.732 cells, were used to develop deforestation occurrences model; while the rest $20 \%$, or about 32.433 cells were used to validate the developed model. Overall process of model development and analysis in this study was conducted using R Studio software.

Logistic regression is a model prediction which has one or more independent variables to predict respond variable with a binary value. Since a binary response, the assuming normal distribution cannot be used, especially if we use ordinary least squares to compute the coefficient parameters regression. The logistic equation is stated in terms of the probability that $\mathrm{Y}=1$, which is $\hat{p}$, and the probability that $\mathrm{Y}=0$, which is $1-\tilde{p}$.

$\ln \left(\frac{\tilde{p}}{1-\tilde{p}}\right)=\beta_{0}+\beta_{1} * X_{1}+\beta_{2} * X_{2}+\ldots+\beta_{i} * X_{i}$

With estimates of the coefficient regression can be computed from the equation using the complementary function for the logarithm, e. Given a particular value of $X$, we can calculate the expected probability that $\mathrm{Y}=1$. Basic equation of logistic regression used to develop spatial model of deforestation in this study can be written as follow (Linkie et al., 2010):

$P=\frac{\operatorname{Exp}\left(\beta_{0}+\beta_{1} * X_{1}+\beta_{2} * X_{2}+\beta_{3} * X_{3}+\ldots+\beta_{i} * X_{i}\right)}{1+\operatorname{Exp}\left(\beta_{0}+\beta_{1} * X_{1}+\beta_{2} * X_{2}+\beta_{3} * X_{3}+\ldots+\beta_{i} * X_{i}\right)}$

Where $\mathrm{P}$ is the probability that deforestation occurs, $\beta_{0}$ is the intercept and the are the estimated coefficients associated with the independent $\left(\mathrm{X}_{\mathrm{i}}\right)$ variables.

Table 2: Data partition per stratum

\begin{tabular}{lccc}
\hline \multirow{2}{*}{ Strata } & \multicolumn{2}{c}{ Number of cells partitioned } & Total Cells \\
\cline { 2 - 3 } & Train Set (80\%) & Test Set (20\%) & (100\%) \\
\hline Chromic Luvisol (Lc) & 2346 & 586 & 2932 \\
Dystic Histosol (Od) & 6713 & 1678 & 8391 \\
Dystric Cambisol (Bd) & 10740 & 2685 & 13425 \\
Dystric Fluvisol (Jd) & 42 & 11 & 53 \\
Humic Acrisol (Ah) & 59550 & 14887 & 74437 \\
Humic Andosol (Th) & 19220 & 4805 & 24025 \\
Humic Cambisol (Bh) & 15750 & 3937 & 19687 \\
Humic Ferrasol (Fh) & 1196 & 299 & 1495 \\
Orthic Acrisol (Ao) & 12666 & 3167 & 15833 \\
Rendzina (E) & 527 & 132 & 659 \\
Vitric Andosol (Tv) & 982 & 246 & 1228 \\
\hline Total cells & 129732 & 32433 & 162165 \\
\hline
\end{tabular}

Remark: size of each cell is $0.0045 \times 0.0045$ decimal degree or about $0.5 \times 0.5 \mathrm{~km}$ 


\section{Model Evaluation}

After deforestation occurrences model has been developed, it is necessary to do the goodness of fit test through the z-test, likelihood ratio test, and also calculation of area under Receiver Operating Characteristic curve, that has been also known as AUC test. In addition to those tests, calculations for the accuracy of the existing model are also done by comparing prediction values with actual values from testing data set that had been partitioned previously. For this purpose, we applied confusion matrix, in which that the accuracy of a prediction model was calculated as a ratio (\%) between the sum of frequencies of data from model and actual which are no deforestation and no deforestation (True Negative $=\mathrm{TN}$ ), deforestation and no deforestation (False Positive $=F P$ ), no deforestation and deforestation (False Negative $=$ FN), deforestation and deforestation (True Positive $=\mathrm{TP}$ ) divided by total number of testing cells, as illustrated in Table 3.

\section{Result and Discussion}

\section{Distribution Trend of Deforestation in Sumatra}

Primary information in regard to the occurrences of deforestation in Sumatra Island related to its influencing variables is presented in Table 4. Based on this table, it can be reported that deforestations in relation with distance to residential area were mainly observed in the closest distance class of less than 0.08 decimal degree (or about less than $8.9 \mathrm{~km}$ in equatorial region like Sumatra-Indonesia). Table 4 has also shown that about $90.3 \%$ of deforestations happened in the area with road density of less than $168 \mathrm{dd} / \mathrm{dd}^{2}$ (or about $1.5 \mathrm{~km} / \mathrm{km}^{2}$ ), while highest class of road density $(168<-<252 \mathrm{dd} /$ $\mathrm{dd}^{2} \gg 1.5<-<2.26 \mathrm{~km} / \mathrm{km}^{2}$ ) was only related to $9.7 \%$ of forest clearing activities. Considering the distribution trend of these human activity related variables, it seems that deforestations in Sumatra were likely to taking place in forest area with closer distance to nearby villages, while having low to moderate road network availability. According to the (Linkie et al., 2010) this kind of deforestation pattern may happen since it was driven by the availability of man power, logistical support provided in the nearest residential areas, the availability of enough access to forest resources, and low monitoring from the authorities given the limitation of major roads to conduct regular forest security patrols.

Moving on to physiographic variables, as illustrated in Table 4, it seems that deforestations in Sumatra mostly occurred in flat forest areas with sloping level of less than $19 \%$ and elevation less than 870 meters above sea level. This finding is consistent with (Linkie et al., 2010) and (Margono et al., 2012), who argued that low level of slope and elevation demand easier approach of forest clearing and lower cost for forest resources extractions, particularly wood. Meanwhile, looking at the type of soil, still as depicted in Table 4, it can be seen that half of forest clearing activities in Sumatra were taken place in humic acrisols areas. (Buol, 2013) and (Sakata et al., 2015) reported that this type of soil is having moderate rate of fertility, vastly found in humid tropical region, and suitable for development of oil palm plantation. Therefore, it is quite unsurprising why deforestations in

Table 3: Confusion matrix to calculate the accuracy of deforestation occurrences model

\begin{tabular}{lll}
\hline & $\begin{array}{l}\text { Predicted: } \\
\text { No Deforestation (0) }\end{array}$ & $\begin{array}{l}\text { Predicted: } \\
\text { Deforestation Occur (1) }\end{array}$ \\
\hline $\begin{array}{l}\text { Actual: } \\
\text { No Deforestation (0) }\end{array}$ & True Negative (TN) & False Positive (FP) \\
\hline $\begin{array}{l}\text { Actual: } \\
\text { Deforestation Occur (1) }\end{array}$ & False Negative (FN) & True Positive (TP) \\
\hline
\end{tabular}

Remark: Model accuracy $=(\mathrm{TN}+\mathrm{TP}) /($ Total Cells $)$; where total cells $=\mathrm{TP}+\mathrm{TN}+\mathrm{FP}+\mathrm{FN}$ 
Table 4: The occurrences of deforestation in Sumatra Island related to influencing variables

\begin{tabular}{|c|c|c|}
\hline Variables & Classes & Deforestation occurrences \\
\hline \multirow[t]{4}{*}{ Distance to residential } & $0 \leq-<0.08 \mathrm{dd}$ & $66.1 \%$ \\
\hline & $0.08 \leq-<0.16 \mathrm{dd}$ & $28.0 \%$ \\
\hline & $0.16 \leq-<0.24 \mathrm{dd}$ & $5.9 \%$ \\
\hline & $0 \leq-<84 \mathrm{dd} / \mathrm{dd}^{2}$ & $54.0 \%$ \\
\hline \multirow[t]{2}{*}{ Road density } & $84 \leq-<168 \mathrm{dd} / \mathrm{dd}^{2}$ & $36.3 \%$ \\
\hline & $168 \leq-<252 \mathrm{dd} / \mathrm{dd}^{2}$ & $9.7 \%$ \\
\hline \multirow[t]{3}{*}{ Elevation } & $0 \leq-<870$ m.asl & $58.7 \%$ \\
\hline & $870 \leq-<1740$ m.asl & $37.8 \%$ \\
\hline & $1740 \leq-<2610$ m.asl & $3.5 \%$ \\
\hline \multirow[t]{3}{*}{ Slope } & $0 \leq-<19 \%$ & $71.0 \%$ \\
\hline & $19 \leq-<38 \%$ & $28.1 \%$ \\
\hline & $38 \leq-<57 \%$ & $0.9 \%$ \\
\hline \multirow[t]{11}{*}{ Soil type } & Chromic Luvisol (Lc) & $0.9 \%$ \\
\hline & Dystic Histosol (Od) & $17.6 \%$ \\
\hline & Dystric Cambisol (Bd) & $2.9 \%$ \\
\hline & Dystric Fluvisol (Jd) & $0.1 \%$ \\
\hline & Humic Acrisol (Ah) & $50.0 \%$ \\
\hline & Humic Andosol (Th) & $7.7 \%$ \\
\hline & Humic Cambisol (Bh) & $9.8 \%$ \\
\hline & Humic Ferrasol (Fh) & $0.2 \%$ \\
\hline & Orthic Acrisol (Ao) & $10.1 \%$ \\
\hline & Rendzina (E) & $0.5 \%$ \\
\hline & Vitric Andosol (Tv) & $0.1 \%$ \\
\hline
\end{tabular}

Remark: $\mathrm{dd}=$ decimal degree; $1 \mathrm{dd} \approx 111.364 \mathrm{~km}($ NASA, 2019)

Sumatra happened on this soil type, since one of the main driver of forest clearing in the island is to provide land for oil palm expansion (Linkie et al., 2010; Margono et al., 2012).

Spatial Model for Predicting Deforestation in Sumatra

A reliable approach to identify the vulnerability of certain areas to deforestation and to establish a deforestation risk model can be the combination of logistic regression analysis and Geographical Information System. This kind of model is reported in this manuscript, in which that the probability level of deforestation occurrences in Sumatra Island is mapped based on physiographic variables (e.g. elevation and slope), soil type variables, as well as human activity variables (e.g. distance to residential area and road network density). Result of spatial model development, goodness of fit tests, as well as validation for accuracy are presented in Table 5 .

Model used (Table 5) can be mathematically (1) written as follow:

$$
\mathrm{P}=\frac{\operatorname{Exp}\{-1.67+(-20.99 * \text { Distance Residential })+\cdots+(-0.888 * \text { Soil Type Vitric Andosol })\}}{1+\operatorname{Exp}\{-1.67+(-20.99 * \text { Distance Residential })+\cdots+(-0.888 * \text { Soil Type Vitric Andosol })\}}
$$


Table 5: Explanatory variables and significance levels for deforestation occurrences model

\begin{tabular}{lrrrr}
\hline Variables & Estimate & Std. Error & Z value & Pr( $>|\mathbf{z}|)$ \\
\hline (Intercept) & $-1.67 \mathrm{E}+00$ & $1.01 \mathrm{E}-01$ & -16.429 & $<2 \mathrm{e}-16^{* * *}$ \\
Distance_Residential & $-2.09 \mathrm{E}+01$ & $2.98 \mathrm{E}-01$ & -70.466 & $<2 \mathrm{e}-16^{* * *}$ \\
Road_Density & $8.10 \mathrm{E}-03$ & $2.81 \mathrm{E}-04$ & 28.858 & $<2 \mathrm{e}-16^{* * *}$ \\
Elevation & $-5.90 \mathrm{E}-04$ & $2.47 \mathrm{E}-05$ & -23.917 & $<2 \mathrm{e}-16^{* * *}$ \\
Slope & $-1.21 \mathrm{E}-02$ & $1.28 \mathrm{E}-03$ & -9.417 & $<2 \mathrm{e}-16^{* * *}$ \\
Soil_TypeDystic Histosol (Od) & $3.19 \mathrm{E}+00$ & $1.03 \mathrm{E}-01$ & 31.151 & $<2 \mathrm{e}-16^{* * *}$ \\
Soil_TypeDystric Cambisol (Bd) & $1.01 \mathrm{E}-01$ & $1.06 \mathrm{E}-01$ & 0.957 & 0.338743 \\
Soil_TypeDystric Fluvisol (Jd) & $1.37 \mathrm{E}+00$ & $3.56 \mathrm{E}-01$ & 3.841 & $0.000123 * * *$ \\
Soil_TypeHumic Acrisol (Ah) & $1.60 \mathrm{E}+00$ & $9.47 \mathrm{E}-02$ & 16.888 & $<2 \mathrm{e}-16^{* * *}$ \\
Soil_TypeHumic Andosol (Th) & $1.02 \mathrm{E}+00$ & $9.98 \mathrm{E}-02$ & 10.238 & $<2 \mathrm{e}-16^{* * *}$ \\
Soil_TypeHumic Cambisol (Bh) & $1.24 \mathrm{E}+00$ & $9.81 \mathrm{E}-02$ & 12.647 & $<2 \mathrm{e}-16^{* * *}$ \\
Soil_TypeHumic Ferrasol (Fh) & $6.91 \mathrm{E}-01$ & $2.01 \mathrm{E}-01$ & 3.446 & $0.000570 * * *$ \\
Soil_TypeOrthic Acrisol (Ao) & $9.05 \mathrm{E}-01$ & $9.83 \mathrm{E}-02$ & 9.206 & $<2 \mathrm{e}-16 * * *$ \\
Soil_TypeRendzina (E) & $2.03 \mathrm{E}+00$ & $1.59 \mathrm{E}-01$ & 12.786 & $<2 \mathrm{e}-16^{* * *}$ \\
Soil_TypeVitric Andosol (Tv) & $-8.88 \mathrm{E}-01$ & $3.95 \mathrm{E}-01$ & -2.25 & $0.024454 *$ \\
\hline
\end{tabular}

Likelihood ratio test $=\mathrm{P}$ value $<0.001$

$\mathrm{AUC}=0.79$

Accuracy of correct predicted values $=90 \%$

Considering the coefficients and values of logistic regression-based model in Table 5, it seems that distance to residential areas and soil type are indeed the most influencing variables in determining the probability of deforestation occurrences in Sumatra. In sequence manner, both variables are then supported by slope, road density, and elevation. Based on obtained values of $\mathrm{z}$ test, it can be reported that in general, all of independent variables shows significant contribution to the developed model. Furthermore, the likelihood ratio test result has obtained p-value of below 0.001, meaning that established model in this study is highly significant to predict the occurrences of deforestation in Sumatra, as also explained by (Mangiafico, 2015).

From Table 5, at very close areas of $<0.08 \mathrm{dd}$, middle area around $<0.16$ $\mathrm{dd}$, and relative far the area from forest around $<0.24 \mathrm{dd}$, the probability of deforestation are exp $(-1,67+-2.09 \times 10 * 0.08) /$ $(1+\exp (-1,67+-2.09 \times 10 * 0.08))=0.034158$, $\exp (-1,67+-2.09 \times 10 * 0.16) /(1+\exp$ $(-1,67+-2.09 \times 10 * 0.16))=0.006600, \exp (-$ $1,67+-2.09 \times 10 * 0.24) /(1+\exp (-1,67+-$ $2.09 \times 10 * 0.24))=0.001050$. It can be said that the farther the distance from the forest, the probability of deforestation decreases. Every increase of $1 \mathrm{dd}$, the probability of deforestation decreased by $(\exp -20,9)=0.000000000838003$ times.

Area with road density from 0 up to $84 \mathrm{dd} /$ $\mathrm{dd}^{2}, 84$ up to $168 \mathrm{dd} / \mathrm{dd}^{2}$, and 168 up to $252 \mathrm{dd} /$ $\mathrm{dd}^{2}$ have probability of deforestation are exp($1,67+0.0081 * 84) /(1+\exp (-1,67+0.0081 * 84))=$ $0.270991, \exp (-1,67+0.0081 * 168) /(1+\exp (-$ $1,67+0.0081 * 168))=0.423310$, and $\exp (-$ $1,67+0.0081 * 252) /(1+\exp (-1,67+0.0081$ $* 252)=0.572045$. Increasing road density will increase probability of deforestation. Each increase of $1 \mathrm{dd} / \mathrm{dd}^{2}$ the chance of deforestation increased by $\exp (0.0081)=1.008132894$ times. 
Location with elevation around 0 up to $870 \mathrm{~m}$.asl, 870 up to $1740 \mathrm{~m}$.asl, and 1740 up to $2610 \mathrm{~m}$.asl have probability of deforestation are $\exp (-16.67-0,00059 * 870) /(1+\exp (-16.67-$ $0,00059 * 870))=0.126021, \exp (-16.67-0,00059 *$ $1740) /(1+\quad \exp (-16.67 \quad-0,00059 * 1740))=$ $0.063174, \exp (-16.67-0,00059 * 2610) /(1+\exp (-$ $16.67-0,00059 * 2610))=0.038795$. Increasing elevation location will decrease the probability of deforestation. Each increasing of $1 \mathrm{~m} . \mathrm{msl}$ will decrease of $\exp (-0.0059)=0,999410174$ times.

Location with slope around 0 up to 19 $\%, 19 \%$ up to $38 \%$, and $38 \%$ up to $57 \%$ have probability of deforestation are $\exp (-$ $16.67-0,0121 * 19) /\left(1+\exp \left(-16.67 \quad-0,0121^{*}\right.\right.$ $19))=0.130120, \quad \exp (-16.67 \quad-0,0121 * 38) /(1+$ $\exp (-16.67-0,0121 * 38))=0.106234$, and $\exp (-$ $16.67-0,0121 * 57) /(1+\exp (-16.67 \quad-0,0121 *$ $57)=0.086298$. Increasing of slope will decrease the probability of deforestation.

With based of Chromic Luvisol (Lc) for probability of deforestation, Dystic Histosol (Od), Dystric Cambisol (Bd) Dystric Fluvisol (Jd), Humic Acrisol (Ah), Humic Andosol (Th), Humic Cambisol (Bh), Humic Ferrasol (Fh), Orthic Acrisol (Ao), Rendzina (E), and Vitric
Andosol (Tv) have probability of deforestation are $24,28842744,1.106276642,3.35350695$, $4.953032424, \quad 2.773194764, \quad 3.455613465$, $1.95710246, \quad 2.471931923, \quad 7.614086359$, 0.411477886 time probability of deforestation at Chromic Luvisol (Lc).

Further examination on model's value of area under the Receiver Operating Characteristic (ROC) curve that has also been widely known as the AUC, shows that developed model in this study is able to obtain AUC value of 0.79. As stated by (Massada et al., 2013), this level of AUC value can be interpreted that developed model is posing moderate classification ability to predict the occurrences of certain event. The graphical illustration of this AUC test result is presented in Figure 2.

Additionally, model validation is confirmed that developed model can produce overall accuracy level of correct predicted value of $90 \%$. Although, developed model in this study is already having high level of overall accuracy, however, it should be kept in mind that relationships among variables may change over time, so that periodic updating is desirable. Meanwhile, using the binary logistic


Figure 2: Graphical illustration of AUC test result 
regression model (Table 5), the prediction map of deforestation occurrences in Sumatra is then produced, and the result is presented in Figure 3. From this map, it can be seen that the probability of deforestation is ranging from 0 to 0.99. As suggested by Prasetyo et al. (2009) and (Mohammadi et al. (2013) cut-off point of 0.5 was used to explained the agreement between areas predicted to emerge the occurrence of deforestation and areas where deforestation has actually occurred. Considering this notion, areas with predicted probability of deforestation occurrence 0.5 should be seen to be highly prone to deforestation occurrence.

\section{Conclusion}

This study has showed that a combination between logistic regression-based modelling and Geographical Information System (GIS) is indeed suitable for determining the probability of deforestation occurrences in Sumatra Island. Analysis conducted in this study has revealed that physiographic variables (e.g. elevation and slope), soil type variables, as well as human activity variables (e.g. distance to residential area and road network density) have high significant correlation with deforestation. In addition to this, logistic regression combined with GIS-based data inventories are useful for mapping probability of incoming deforestation, since each of influencing variable can be thoroughly analyzed in this method. Such

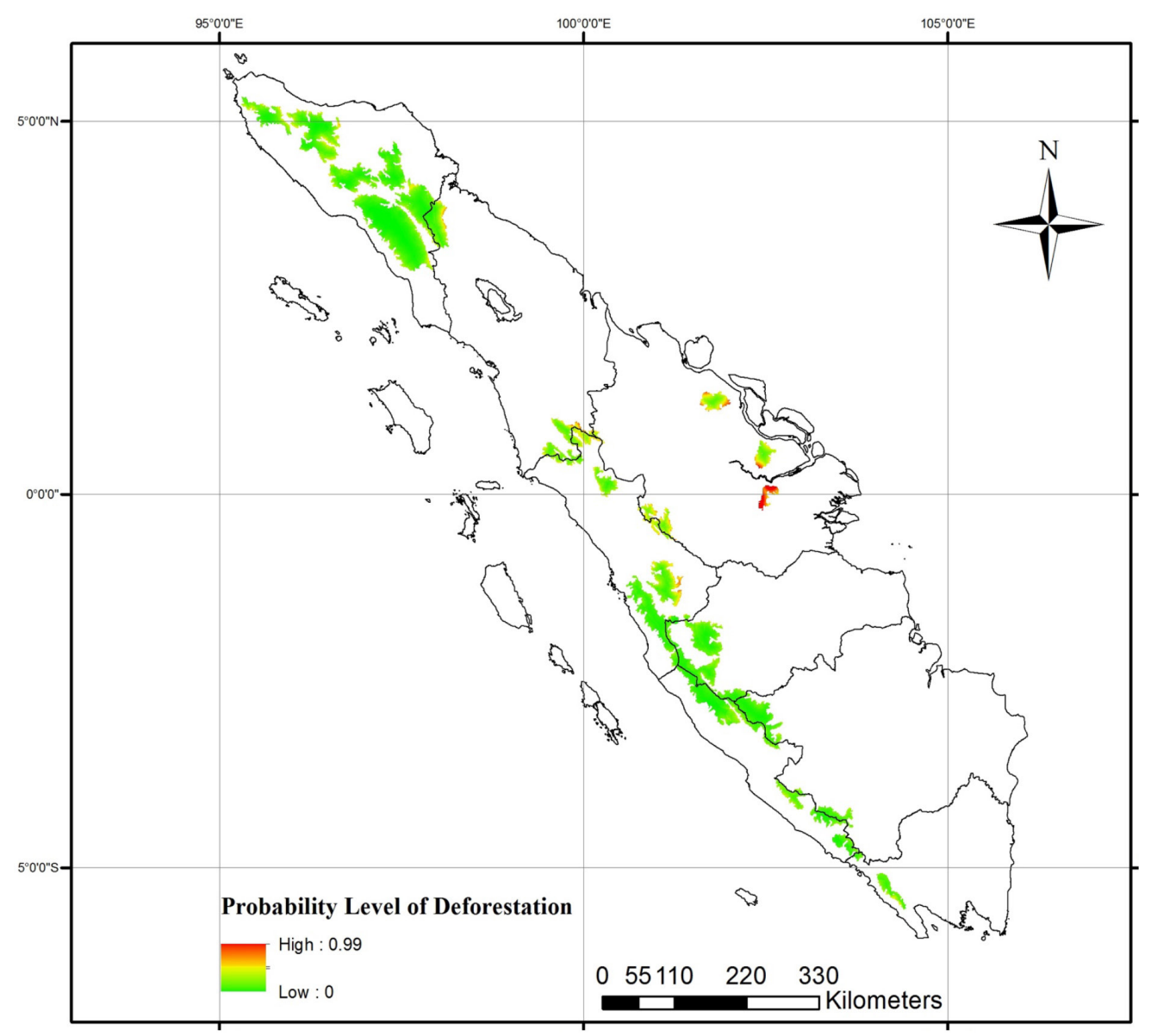

Figure 3: Map of deforestation probability 
valuable information regarding areas most likely to be affected by deforestation may help the authorities to easily identify high deforestation risk locations and effectively manage those areas.

\section{Acknowledgements}

The authors are grateful to the World Resources Institute (WRI), the Agency for Geospatial Information-Republic of Indonesia, the United States Geological Survey (USGS), as well as the Food and Agricultural Organization (FAO), who have supported us with valuable data required in this study. Sincere thanks are also due to all reviewers of this manuscript who have provided us valuable advices and suggestions.

\section{References}

BPS-Statistics Indonesia. (2017). Regional Extent and Number of Islands per Province 2002-2016. Jakarta: BPS-Statistics Indonesia.

BPS-Statistics Indonesia. (2018). The Extent of Land Cover Inside and Outside Forest Area 2017. Jakarta: BPS-Statistics Indonesia.

Buol, S. W. (2013). Tropical soils: Humid tropical. Reference Module in Earth Systems and Environmental Sciences. https://doi.org/10.1016/B978-0-12409548-9.05324-0

Catry, F. X., Moreira, F., Duarte, I., \& Acacio, V. (2009). Factors affecting post-fire crown regeneration in cork oak (Quercus suber L.) trees. European Journal of Forest Research, 128(3), 231-240.

DeFries, R. S., Rudel, T., Uriarte, M., \& Hansen, M. (2010). Deforestation driven by urban population growth and agricultural trade in the twenty-first century. Nature Geoscience, 3, 178-181.

Linkie, M., Rood, E., \& Smith, R. J. (2010). Modelling the effectiveness of enforcement strategies for avoiding tropical deforestation in Kerinci Seblat National Park, Sumatra. Biodiversity and Conservation, 19, 973-984.
Mangiafico, S. S. (2015). An R Companion for the Handbook of Biological Statistics. New Brunswick, New Jersey: Rutgers Cooperative Extension.

Margono, B. A., Turubanova, S., Zhuravleva, I., Potapov, P., Tyukavina, A., Baccini, A., ... \& Hansen, M. C. (2012). Mapping and monitoring deforestation and forest degradation in Sumatra (Indonesia) using Landsat time series data sets from 1990 to 2010. Environmental Research Letter, 7 , 1-16.

Massada, A. B., Syphard, A. D., Stewart, S. I., \& Radeloff, V. C. (2013). Wildfire ignitiondistribution modelling: A comparative study in the Huron-Manistee National Forest, Michigan, USA. International Journal of Wildland Fire, 22, 174-183.

Mohammadi, F., Bavaghar, M. P., \& Shabanian, N. (2013). Forest fire risk zone modelling using logistic regression and GIS: An Iranian case study. Small-scale Forestry. Small-Scale Forestry. https://doi. org/10.1007/s11842-013-9244-4

Pan, J., Wang, W., \& Li, J. (2016). Building probabilistic models of fire occurence and fire risk zoning using logistic regression in Shanxi Province, China. Natural Hazards, 81, 1879-1899.

Prasetyo, L. B., Kartodiharjo, H., Suryo, A., Okarda, B., \& Setiawan, Y. (2009). Spatial model approach on deforestation of Java Island, Indonesia. Journal of Integrated Field Science, 6(3), 37-44.

Sakata, R., Shimada, S., Arai, H., Yoshioka, N., Yoshioka, R., Aoki, H., ... \& Inubushi, K. (2015). Effect of soil types and nitrogen fertilizer on nitrous oxide and carbon dioxide emissions in oil palm plantations. Soil Science and Plant Nutrition, 61, 48-60.

Sydenstricker-Neto, J. (2012). Population and deforestation in the Brazilian Amazon: A mediating perspective and a mixedmethod analysis. Population and Environment, 34, 86-112. 